\title{
Investment with Intangible Assets of Chinese Research Institutions
}

\author{
Liu Yanrui ${ }^{1}$, Ding Minglei ${ }^{2}$ \\ ${ }^{1}$ Department of Science and Technology Policy, Beijing Radiation Center, Beijing Research Center for Science of Science, Beijing, China \\ ${ }^{2}$ Institute of Comprehensive Development, Chinese Academy of Science and Technology for Development, Beijing, China
}

\section{Email address:}

liuyr008@163.com (Liu Yanrui), dingml@casted.org.cn (Ding Minglei)

\section{To cite this article:}

Liu Yanrui, Ding Minglei. Investment with Intangible Assets of Chinese Research Institutions. American Journal of Applied Scientific Research. Vol. 4, No. 2, 2018, pp. 28-32. doi: 10.11648/j.ajasr.20180402.14

Received: September 10, 2018; Accepted: October 18, 2018; Published: November 10, 2018

\begin{abstract}
Chinese research institutions and universities used to have to face many problems when they invested with their intangible technical assets, such as complicated examination and approval procedures for the disposal of scientific and technological achievements, unreasonable design of income tax system for technology investment, the difficulty in executing equity incentives, and the lack of motivation to researchers. The newly revised Law of the People's Republic of China on Promoting the Transformation of Scientific and Technological Achievements in 2015, and the supporting policies and measures subsequently introduced improved the systems regarding the management of scientific and technological achievements and technology investment. However, after a large number of interviews and literature research, the authors find that now there are still some obstacles for value-based investment, such as the mandatory technology investment evaluation does not conform to the law of the transformation of scientific and technological achievements, corporate capital increase and exit mechanism are not smooth after technology investment, ownership of state-owned influence the enthusiasm of the transformation of scientific and technological achievements. At the same time, get the conclusion that duties, obligations, and interests of researchers, technology transfer personnel and institutions, legal entities, and government departments are important factors that influence the transfer of technology conducted by research institutions and universities; As a special commodity, scientific and technological achievement can realize their real value only after it enters the market. Its industrialization process may be successful or failed, as there are lots of uncertainties and risks; Existing state-owned asset management policy equates technical intangible assets with tangible assets management, and stipulates that public research institutions and universities must evaluate the value of scientific and technological achievements they possess or enterprises invested when investing with technology, increasing capital or withdrawing shares, to fulfill the obligation to maintain and increase the value of state-owned assets of scientific and technological achievements. Formalistic assessment, long review cycle and the lack of evaluation standards are obstacles for investment with technical intangible assets by research institutions. For this, the author suggests exploring the mixed ownership for scientific and technological achievements, establishing special intangible assets evaluation criteria based on The General Rules for Science and Technology Research Projects Evaluation, and a system combining mandatory assessment evaluation and selective evaluation.
\end{abstract}

Keywords: Chinese Research Institutions and Universities, Technology Investment, State-Owned Assets, Evaluation, Mixed Ownership

\section{Introduction}

Technical intangible assets are main achievements of research institutions (mostly fiscally-funded research institutions and universities) in carrying out innovative activities. As China steadily increases its input in the field of science and technology, the quantity of technical intangible assets has been on a rise, Led by research institutions, the growth of high-tech enterprises is facilitated via technology investment, which is of great significance to establish a long-term cooperation mechanism and a bond of interests between industry, university, and research, and accelerate the transformation of scientific and technological achievements 
into real productivity. [1]

\subsection{Literature Review}

As the product of scientific and technological innovation, technical intangible assets are also a property right of the owner, which is legally protected in the form of intellectual property. How to scientifically assess, record and report about the value of intangible assets has become a hot issue in the study of scientific and technical innovation and management as well as accounting theories, due to the following reasons: its highly technical and knowledge-based property, the excess profits it brings to holders, the high risk of value conversion process, and the weak correlation between input and output.

In 1993, Accounting Standard for Business Enterprises was enacted in China, in which intangible assets are defined as assets accessible to enterprises for long-term without physical forms, which include patent rights, non-patented technologies, trademark rights, copyrights, land use rights, franchise rights, business reputation, etc. The Accounting Standard for Business Enterprises - Intangible Assets [2] enacted in 2006 defines intangible assets as "identifiable non-monetary assets without physical forms owned or controlled by enterprises". According to the above definitions, state-owned technical intangible assets refer to national patents, non-patented technologies, technology secret franchise and other intangible assets possessed by enterprises, universities and research institutions.

Studies on technical intangible assets conducted by Chinese scholars mainly focus on the evaluation and management of intangible assets. Wang Juncai and Luo Xiaowen (2006) expounded on the defects in pricing knowledge-based intangible assets from three aspects: investment prospects, specialist and expertise, according to the characteristics of knowledge-based intangible assets. [3] Xue Shijia (2012) held that it was necessary to improve the structure of state-owned intangible assets assessment from several aspects-assessment management models, assessment scope, assessment methods and related supporting measures, so as to solve the problems existed in the practice of state-owned intangible assets assessment in China. [4] Yue Xianping (2010) reviewed the assessment of patented assets in the process of trading intellectual property at home and abroad. [5] Zhang Ying (2011) analyzed and discussed the legal issues pertaining to the contribution of intangible assets, and proposed the suggestions for the improvement of China's legal system of the contribution of intangible assets. [6] Chen Baoming (2014) proposed that the management of state-owned technical intangible assets was the arrangement of property rights system in nature and that the transformation of scientific and technological achievements was hindered by the current system of state-owned technical intangible assets management policy hinders to some extent. [7]

As for problems existed in investment with technical intangible assets, Zhao Jie et al. (2011) believed that technology investment conducted by research institutions and universities was problematic in the following aspects: the ownership of stock rights, the proportion and distribution of equity incentives, and the approval procedures for technology investment. [1] Chen Baoming (2012) argued that technology investment by research institutions and universities was confronted with obstacles sucn as state-owned asset management, governance structure and taxation. [8]

\subsection{Key Points of Technology Investment Policy After 2015}

Technology investment is an advanced form of transformation of scientific and technological achievement in market economy conditions as well as an important approach to combine technologies with capitals. [8] When Chinese research institutions and universities invested with technology, they met problems including complicated procedures for the examination and approval of the scientific and technological achievements, less reasonable design of income tax system for technology investment, difficulty in executing equity incentive measures, and under-motivated researchers for the transformation.

According to the Law of the People's Republic of China on Promoting the Transformation of Scientific and Technological Achievements (hereinafter referred to as the "Law on Promoting the Transformation of Scientific and Technological Achievements") newly revised in 2015, the right of use, disposal and usufruct has been delegated to research institutions and universities, with the cancel of approval and filing procedures for the economic behavior of technology investment. At the same time, the receivers of equity incentives in technology investment and the distribution mechanism have been clarified, and research institutions and universities have been given with more autonomy on the disposal of scientific and technological achievements. Provisions on Implementing the Law of the People's Republic of China on Promoting the Transformation of Scientific and Technological Achievements (DRC [2016] No. 16) clearly stipulates that "organization leaders are exempted from the responsibility for decisions arising from any change in the value of the transformed of scientific and technological achievements after pricing scientific and technological achievements, on the premise of fulfilling due diligence without gaining unlawful interests", which solves the problem that the transformation is under-motivated in the process of technology investment because "leaders are afraid of taking responsibilities". In Notice on Income Tax Policy for Improving Income Tax Policy about Equity Incentives and Technology Investment of the Ministry of Finance, State Administration of Taxation and Ministry of Science and Technology (Finance \& Taxation [2016] No. 101), and Notice on the Implementation of Income Tax Policy about Equity Incentives and Technology Investment of State Administration of Taxation (SAT [2016] No. 496), selective preferential tax policy on technology investment are introduced, which upgraded the income tax system for technology investment. By enacting the above mentioned laws and regulations, the impetus and vigor of Chinese public research institutions can be greatly stimulated to invest in enterprises with technology.

However, according to the current Company Law and regulations of China related to state-owned assets 
management, value assessment is still needed for research institutions and universities when investing in enterprises by their technical intangible achievements, and an overall evaluation of the enterprise is required in case of capital increase or exit after the investment, which, however decreases the efficiency of transformation of scientific and technological achievements and goes against the spread of the form of technology investment in such transformation.

\section{Remained Obstacles for Investment with Technical Intangible Assets}

\subsection{Mandatory Technology Investment Evaluation and Pricing Is Not Scientific and Reasonable}

Investment with scientific and technological achievements as intangible assets is actually a kind of contribution in the non-monetary form. The scientific, reasonable, true, fair and just determination of technical value is conducive to protecting the respective rights and interests of technology owners and technology buyers. In practice, there are three main pricing approaches for technology investment: pricing through evaluation, pricing through negotiation, and a hybrid way of the two. Pricing through evaluation aims at determining the value of contributors' technological achievements by asset evaluation agencies. (Assets evaluation agency is an assets evaluation company, accounting firm, audit firm, financial consulting firm or evaluation agency acknowledged by state-owned assets management departments who has qualification certificate for state-owned assets evaluation and corporate capacity), which is essentially a process of quantifying the value of certain technologies. Pricing through negotiation mainly refers to the behavior of pricing based on one-to-one negotiation between two trading parties. According to Article 27 of Company Law of China (2013 version) and regulations about state-owned assets management issued by Ministry of Finance of China, "pricing for contributed non-monetary assets should be evaluated". Whether public research institutions need to assess the value of the scientific and technological achievements in the process of technology investment is not explicitly stipulated in the newly revised Law on the Promotion of the Transformation of Scientific and Technological Achievements of China, However, according to the explanatory text of the Law, it is still necessary to evaluate scientific and technological achievements and put them on records in accordance with laws and regulations about state-owned assets management. [9].

It is hard to determine the value of scientific and technological achievements due to their special characteristics as a commodity. In the process of actual technology investment, pricing during the technology transfer is largely based on factors such as technology maturity, scope of production application, investors' risk tolerance and willingness to take risks. The evaluation procedure will be carried out after a consensus is reached by both parties through negotiation, which is always formalistic. In addition, the approaches used to evaluate tangible assets are often adopted for the evaluation process with a lack of legal basis for the selected evaluation parameters and evaluation criteria, and the subjectivity of evaluators plays a strong role in appraisal of the application prospects and potential market value which is also greatly influenced by individual factors of the evaluated clients. [10]

Mandatory assessment policy usually leads to complicated, cumbersome and high-cost contribution procedures. To conclude deals timely, investors, stockholders, and appraisal agencies often collude with each other and provide false appraisal reports. As a result, the assessment tends to be formalistic with the increase transaction of costs. Sometimes it may affect the timeliness of scientific and technological achievements, discourage investors and fail to prevent the loss of state-owned assets.

\subsection{Capital Increase of Enterprises and the Exit Mechanism Are Not Smooth After Technology Investment}

In addition to the obligation to promote the transformation of scientific and technological achievements, guaranteeing the value maintenance and appreciation of state-owned assets and preventing corresponding loss is also one of the major obligations for Chinese research institutions and universities. Article 18 of the newly revised Law of the People's Republic of China on Promoting the Transformation of Scientific and Technological Achievements stipulates that the right to use and dispose of the scientific and technological achievements shall be given to the organization, which may decide to convert scientific and technological achievements in the form of technology investment on its own. Moreover, the newly revised Law clearly stipulates that all revenues from transforming scientific and technological achievements are owned by the research institution, and those who have made a significant contribution to the transformation will be awarded with more than $50 \%$ of equities. It is worth emphasizing that all revenues obtained from the transformation of scientific and technological achievements is all owned by the unit, Which is a regulation of the right to income in the transformation of scientific and technological achievements without affecting the nature of such scientific and technological achievements as state-owned assets.

According to the stipulations of Interim Measures for the Management of State-owned Assets of Central-level Public Institutions (Ministry of Finance \& Ministry of Education [2008] No. 13) and Interim Measures for the Management of the Use of State-Owned Assets of Central-level Institutions (Ministry of Finance \& Ministry of Education [2009] No. 192), state-owned equity transfer still needs to go through procedures for approval according to different amounts of limit as well as, in accordance with Registration and Administration Measures for the Registration of State-owned Assets of Enterprises and Institutions, it is necessary handle with registration procedures for ownership and related changes, and acquire corresponding registration certificate in advance. In actual practice, the applying process of registration of property right and equity transfer still takes a 
long period of time. Before each capital increase, the company should be evaluated as a whole and the evaluation should be reported to the competent department for review, evaluation, and filing. Long review cycle and high evaluation fees remain one of the obstacles facing the technology investment of public research institutions.

\subsection{Ownership of State-Owned Influence the Enthusiasm of the Transformation Scientific and Technological Achievements}

For scientific and technological achievement inventors, the newly revised Law on Promoting the Transformation of Scientific and Technological Achievements stipulates that research institutions may stimulate and guarantee the enthusiasm of researchers in technology transfer by means of equity incentives. However, universities and research institutions are unable to directly allocate state-owned stocks to researchers. Only corresponding usufruct can be given to them through equity incentives because scientific and technological achievements are state-owned in nature. [11] Transformation of technology investment possessed by Chinese research institutions and universities will give rise to ownership conflicts between current ownership and incentives result in the vicious cycle of "strict management of state-owned assets, achievement ownership possessed by state-owned units, no right to allocate stated-owned equity to individuals by universities, difficulty to accurately motivate researchers, incapability of achievement transfer or illegal transfer and transformation, loss of substantial stated-owned assets". [12] Meanwhile, although related departments have introduced liability exemption for fulfilled duty policy, investigations have found in the process of technology investment that leaders from related units are wondering if the estimated value of scientific and technological achievement possessed is "too high" or "too low", which hinders public research institutions from transforming scientific and technological achievements to a great extent.

\section{Conclusions}

Duties, obligations, and interests of researchers, technology transfer personnel and institutions, legal entities, and government departments are important factors that influence the transfer of technologies conducted by research institutions and universities. As a special commodity, scientific and technological achievements can realize their real value only after entering the market, the industrialization process of which may success or fail because there are lots of uncertainties and risks. However, existing state-owned asset management policy equates technical intangible assets with tangible assets management, and it stipulates that public research institutions and universities must evaluate the value of scientific and technological achievements possessed by them or invested by enterprises when investing with technology, increasing capital or withdrawing shares, so as to fulfill the obligation of value maintenance and appreciation of state-owned scientific and technological achievements.
Formalistic assessment, long review cycle and the lack of evaluation standards are obstacles for investment with technical intangible assets by research institutions.

\section{Prospects}

\subsection{Mixed Ownership Reform of Scientific and Technological Achievements of Research Institutions}

After the Bayh Dole Act was introduced in the US, the conversion rate of scientific and technological achievements in the U.S. has increased substantially. The key is that the Act entitles private sectors to the ownership of federally-funded scientific payoffs, which leads to strong impetus for the transformation of scientific and technological achievements. In 2016, Chengdu issued Several Policy Measures to Promote the Transformation of Scientific and Technologies Achievements of Domestic and Foreign Universities and Colleges in Chengdu, which explicitly proposes to support the mixed ownership system reform of scientific and technological achievements of colleges and universities. At present, China has also begun to implement a pilot policy to grant researchers' ownership and long-term use right of scientific and technological achievements for researchers (Notice on Several Measures to Optimize Scientific Research Management and Improve Scientific Research Performance of the State Council DRC [2018] No. 25). The Patent Law of the People's Republic of China is undergoing the fourth revision now, one of the emphases of which is whether to give researchers from research institutions the ownership legitimacy for scientific and technological achievements.

\subsection{Establishing Specialized Evaluation Criteria for Intangible Assets Based on the General Rules for Science and Technology Research Projects Evaluation}

Article 8 of Scientific and Technological Progress Law, points out that the state establishes and improves the scientific and technological evaluation system conducive to independent innovation. The General Rules for Science and Technology Research Projects Evaluation (GB/T22900-2009) uses a unified and standard language to evaluate scientific and technological projects and achievements, providing a scientific and standardized method for quantitative and standardized evaluation of scientific research projects. Considering the lack of relevant legal basis for the evaluation criteria for technical intangible assets, it is suggested developing pricing standards and procedures for technical intangible assets on this basis.

\subsection{Exploring a System that Combines Mandatory Assessment and Selective Assessments}

Mandatory assessment model is adopted for value judgment of contributed non-monetary assets in China, which increases the possibility of confirming state-owned assets, but increases the establishment costs of companies and fails to effectively guarantee the rights and interests of such 
contribution. In light of international experience, like as Germany, mandatory assessment mechanism is adopted in China. In addition, there are two other models: one is the judgment by the board of directors in the U.S., which requires a sound corporate governance structure to match; the other is the "no evaluation for mandatory assessment and exception" model adopted by France and Japan. That is, mandatory assessment is generally required, but can be selective in situations where certain laws specify. These circumstances can be summarized into two types: the first type is that the total value of the capital contributed does not exceed a certain amount; the second is that although the value of the invested property exceeds a certain amount, it is certified by the relevant subjects with the stipulation of their liabilities.

Article 40 of the Commercial Company Law of France (1967) stipulates that for limited company, if its shareholders reach a consensus and the value of each investment in kind does not exceed 50,000 francs and total value of all investments in kind unevaluated by investment evaluator does not exceed $1 / 2$ of corporate capital. It is recommended to take the French and Japanese models of technology investment assessment for reference and adopt a a hybrid way of mandatory assessment and selective assessment. Selective assessment is allowed when the technology price does not exceed a certain amount and the total value of the contribution does not exceed a certain proportion, for instance, the legal force of pricing through negotiation is acknowledged.

\section{References}

[1] Zhao Jie et al. Study of Problems in Technology Investment in Transformation of Scientific and Technological Achievements [J] Studies in Science of Science, 2011, v. 29; No. (10) 47-51.

[2] Accounting Standard for Business Enterprises No. 6-Intangible Assets [EB/OL]. [2013-11-12] http://kjs.mof.gov.cn/zhuantilanmu/kuaijizhuanzeshishi/20080 6/t20080618_46242.html.

[3] Wang Juncai \& Luo Xiaowen. Analysis of Defects of Knowledge Intangible Assets Pricing [J]. Journal of Central University of Finance \& Economics, 2006, No. (9):88-92.

[4] Xue Shijia. Research on Legal Problems of Intangible Assets Evaluation of Chinese State-owned Enterprises [D]. Master Theses of Zhejiang University, 2012.

[5] Yue Xianping. Evaluation of Patent Assets of the Transaction of IPR at Home and Abroad [J]. Forum on Science and Technology in China, 2010, No. (8): 152-157.

[6] Zhang Ying. Study on Legal Issues about Contribution of Intangible Assets [D]. Master Theses of Northwest University, 2011.

[7] Chen Baoming. Study on Countermeasures to Accelerate the Reform of State-owned Technical Intangible Assets Management [J]. Technology Innovation and Productivity, 2012, No. (9): 6-10.

[8] Chen Baoming. Main Obstacles for Technology Investment in and Solutions [J]. Science, Technology and Law, 2012, v. 100; No. (6): 39-42.

[9] Kan Ke \& Wang Zhigang. Interpretation of Law of the People's Republic of China on Promoting the Transformation of Scientific and Technological Achievements, China Democracy and Legal System Publishing House, 2015: 20-21.

[10] About Technology Investment, https://zhidao.baidu.com/question/54541055.html.

[11] Li Yingbo, Zhou Li, and He Jiankun. Strategic Effect of International Technology Transfer by Research Universities in the Course of Building An Innovative University [J], China Soft Science, 2007, (04): 134-139.

[12] Zhang Mingshen. How to Deal with the Curse of State-Owned Assets Hindering the Technology-Stock --An Example of Mixed Ownership Reform in Chengdu [J], Reform of Economic System, 2017, No. (6): 117. 